\title{
Public Participation in Local Forestry Policy-making after Decentralization: Uncertainties, challenges and expectations in Tanjung Jabung Barat District, Jambi Province
}

By Sudirman, Dede Wiliam and Siân McGrath

\section{Introduction}

The Decentralization process introduced in 1999 has motivated regions to increase their capacity and selfreliance. District governments now have more opportunities to manage their own resources, making them less reliant on the central government and potentially more efficient.

Increased local responsibility is evident in the many district regulations developed since 1999, including the forestry sector. Whilst decentralization certainly brought decision-making closer to local people - the public still does not have enough influence over policy making; and local and national interests often still contradict each other. This causes problems implementing policies on the ground.

This policy brief highlights lessons learned from analysing public participation in developing district forestry regulations in Tanjung Jabung Barat (Tanjabbar), in Indonesia's Jambi province. The main responsibility given to districts (since revoked) was the authority to issue small-scale concession permits of no more than 100 ha inside or outside the state-owned forest estate (Kawasan Hutan). Acting on this new authority, the Tanjabbar district government issued three main regulations, or Perda (the highest district legal instruments). The first was Perda No. $13 / 2002$, known locally as the IPHH regulation. Perda 13 enacted the national decentralisation policy, with four IPHH permit types for logging and collecting non-timber forest products (see Figure 1).

Figure 1. Permits Regulated under Tanjabbar's Small-Scale 100 ha Concession Policy

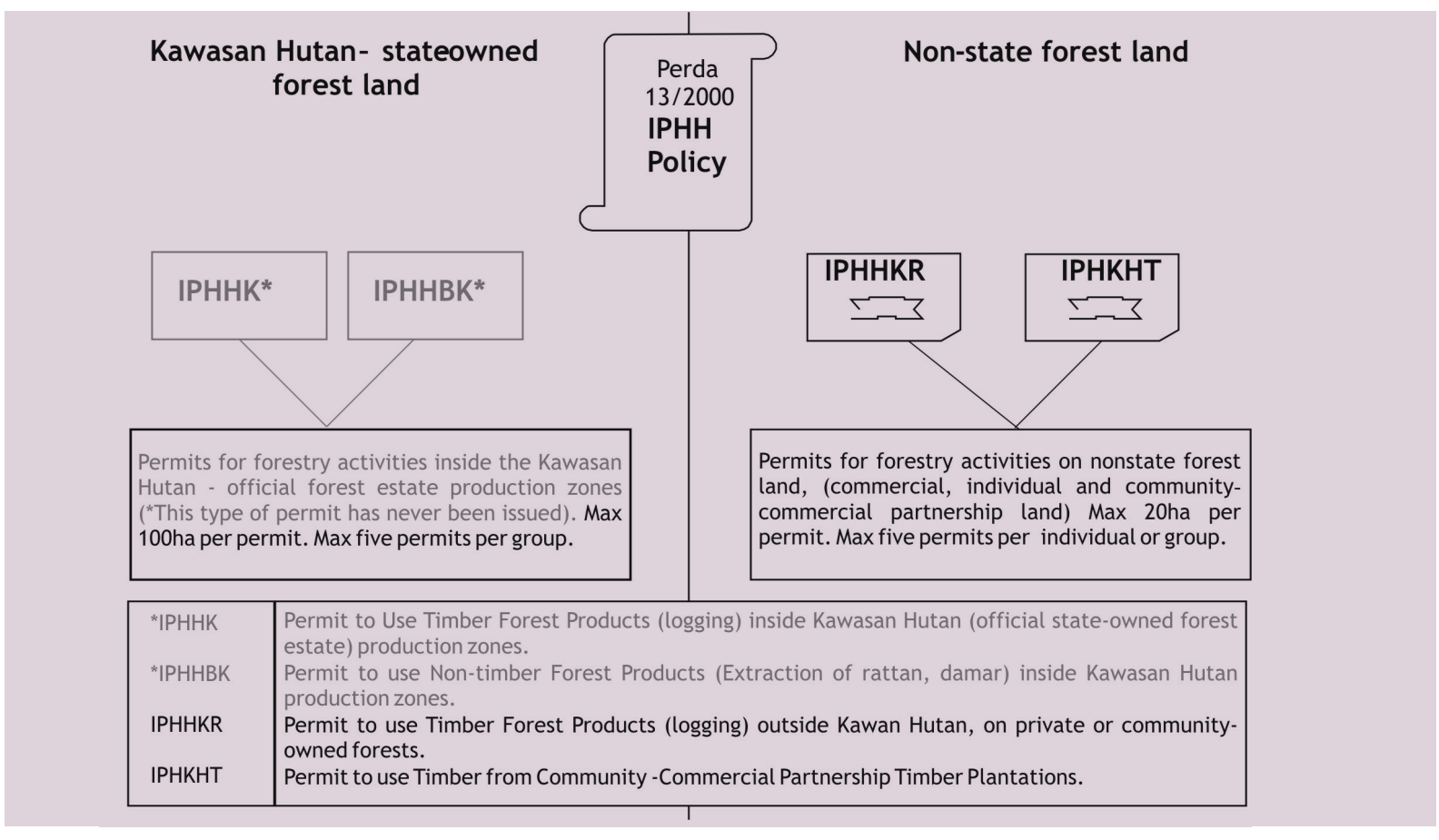


The Tanjabbar government also drafted two other Perdas ${ }^{1}$, regulating tax collection and setting fees. Although a Perda is the highest district regulation, none of these Perda could be implemented without the District Head (Bupati), authorizing their implementation with a special decree ${ }^{2}$. The Bupati has individual authority to pass this lower regulation without public consultation.

Seventy per cent of Indonesia's landmass is classified as Kawasan Hutan, or state-owned forest land. In Jambi province, the state-owned forests were already heavily logged before decentralisation. In Tanjabbar, the total forest cover has declined by almost $40 \%$ in the last 20 years. First, significant areas were excised and allocated for transmigration and oil palm plantations. Further areas were then rezoned for agricultural use. ${ }^{3}$

The remaining forest area mainly comprises loggedover forests, secondary forests and tree plantations, with a small, protected area in the hills. Yet, despite the deforestation and the degraded nature of many logged-over areas, more than half the Tanjabbar district is still officially classified as state-owned forest, with $87 \%$ of that classified as timber "production forest" in 2002. This is actually an increase from the total production area recorded in the 1999 provincial spatial plan.

However, the national policy on small-scale logging concessions only allowed permits inside state-owned "conversion forest" areas, not "production forests". ${ }^{4}$ None of Tanjabbar's Kawasan Hutan is currently classified as "conversion forest". Under the smallscale concession IPHH policy, only two types of permit were issued in Tanjabbar. These only applied to forested areas outside the Kawasan Hutan: on village lands, areas subject to adat claims, and land owned by individuals, commercial firms or under partnership agreements between large corporations and local communities.

The other two permit types were only to be used inside the state-owned forests, including on production areas. This regulation contradicted national policy, ${ }^{5}$ but the district never issued any of these permits. As a result, when the central government revoked the rights of district heads to issue small-scale logging permits ${ }^{6}$, this did not change Tanjabbar's policy or its implementation. The head of Tanjabbar continued to issue permits outside the Kawasan Hutan, as this land had always been outside the Ministry of Forestry's jurisdiction.

The district's forestry Perda all refer to mechanisms for collecting revenue and allocating land. They also simplify the process for obtaining permits to manage and use forest resources. However, they do not regulate forest management, nor environmental and socio-economic impacts.
Limited provisions for these impacts are instead included in a Bupati's Decree setting out the rules and processes for handling IPHH permit applications and providing “logging schedules". Perda 13 also briefly mentions processes for managing logging activities and their impacts, and the permit-holder's obligation to rehabilitate logged over areas. However, the regulation says nothing about how or when these activities should be carried out, or how they will be monitored. The implementing decrees also neglect these issues. Permits are issued for 6 months. Permit holders can request an extension only "if timber production is still possible"7. This implies that extensions cannot be given if there are no more trees to be logged - effectively ruling out extensions for rehabilitation.

This small scale concession policy has facilitated the exploitation of the remaining stands of natural forest areas outside the Kawasan Hutan in Tanjabbar.

At the same time, the Ministry of Forestry has implemented a policy with momentous implications for Tanjabbar's forests inside the Kawasan Hutan.

In 1996 the Ministry of Forestry began issuing timber plantation ( $\mathrm{HTI})$ permits to PT Wira Karya Sakti (WKS), a daughter company of the conglomerate, Sinar Mas Group (SMG). The first permits allocated in Jambi included permits over the former PT Betara Agung Timber, and PT Lontar concession areas in the Tanjabbar district. After decentralization the central government continued to issue new plantation permits in Tanjabbar, including over the former concession areas of PT Sadarnila, PT Loka Rahayu, and PT IFA. The company PT WKS now controls well over 200,000 ha, including most of Tanjabbar's Kawasan Hutan. ${ }^{8}$ These areas have been or are presently being clear felled and replanted with acacia. Consequently, this central policy could spell the end for all natural forests in Tanjabbar's Kawasan Hutan.

This means that there will soon be no significant natural forest areas remaining in Tanjabbar beyond the little remaining in the Bukit Tiga Puluh national park $(9,105 \mathrm{ha})$ and the adjoining former PT Hatma Shanti area. ${ }^{9}$

\section{Recommendations for Reforming Tanjabbar's Forestry Regulations}

Based on a review of Tanjabbar's forestry regulations, policy reforms could address at least four fundamental issues:

\section{Legal Drafting:}

The district regulations refer to defunct central laws superseded by decentralisation and revised national forestry laws introduced in $1999^{10}$. This means district policies contain outdated definitions, terms and formats, and some articles contradict higher regulations. 


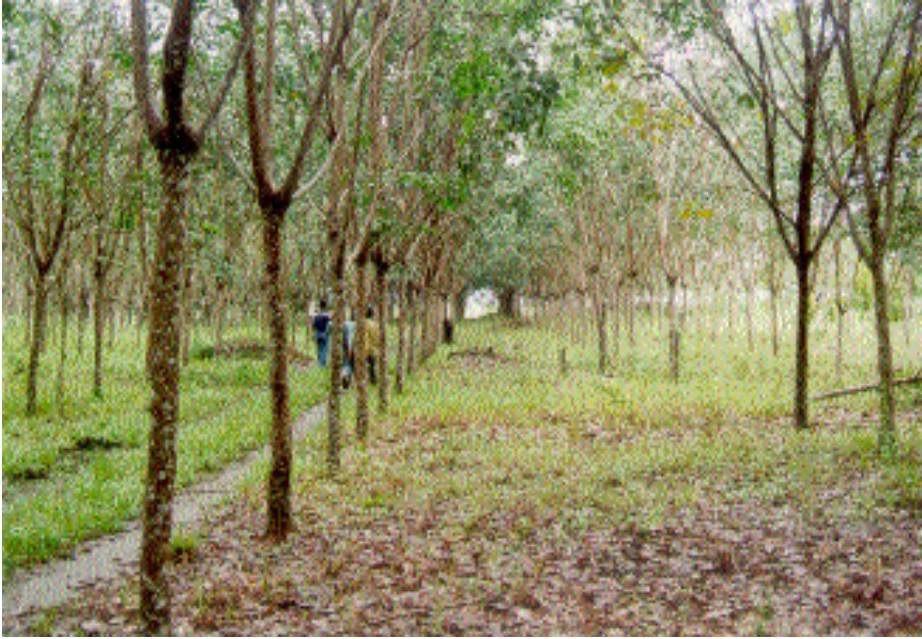

Smallholder Rubber Plantation, Jambi. (Photo by Toni Djogo)

The public was not consulted when local regulations were formulated. This contradicts recommendations in Article 68 of national Forestry Law No. 41, issued in 1999, and Article 24 (5) of Act No. 34, issued in 2000, regarding Regional Taxes and Retributions (see section C).

\section{Weak Enforcement Provisions}

Provisions for monitoring and enforcing district regulations are unclear and weak. For example, Article14 (3) of the district IPHH regulation states simply that the permit for forest product utilization can be revoked if the holders violate "rules and laws". The regulations do not state what the rules are nor which laws. This is very confusing for both permit holders and law enforcement agencies.

\section{Technical Implementation Problems}

Double taxation: Perda No. 15, Article 3 (2 and 3) covers levies for forest plantation permits. This requires concessionaires to pay provisional fees, reforestation funds and forest product levies. Meanwhile, central government also requires concessionaires to pay provisional fees and reforestation funds (DR). The district regulation contradicts a wide range of central government Acts and regulations, namely Act No. 22/1999, Act No. $25 / 1999$, Act No. 41/1999, Act No. 34/2000 Jo Act No. 18/1997, PP No. 25/2000, and PP No. $34 / 2002$.

The introduction of the district authority to levy taxes has enabled illegal timber to be taxed. On the one hand, this timber would otherwise have left the district without contributing to government revenue. On the other, this effectively "legalizes" illegally harvested timber.

\section{Local Policy-making Processes}

There are two methods of local policy-making processes in Jambi province. These are still based on decrees issued by local government heads between 1992 and1993 ${ }^{11}$. With the first method, members of parliament can propose a draft regulation, which is then debated in parliament (Figure 1). This method is only possible if members of Parliament have the expertise and experience required to initiate a draft regulation.

In the second method, local executive bodies initiate the process, which is then submitted to the District House of Representatives (DPRD) with an introductory note written by the Bupati (Figure 2). All policymaking in Tanjabbar follows this second method. Reasons for executive initiation include better executive knowledge about sectoral issues, responsibility for implementing regulations, and poorly qualified parliamentary members.

The process followed for the second method has four phases:

1. Policy Drafting: government offices initiate the first draft. For example, the district forestry office (dinas Kehutanan) would draft a local regulation covering logging.

2. Policy Synchronization: the initiating office then discusses the draft with the secretary of the district's legal bureau (Biro Hukum), including writing, wording and legal norms.

3. Pre-hearing: a local parliamentary committee (Panmus) decides on a discussion schedule.

4. The hearing: this takes place in the local parliament. The hearing has four plenary sessions:

- The first session is based on the Bupati's introductory note to the draft.

- In the second session, parliamentary members share their general perspectives.

- In the third session, commonly called Rapat Pansus, the special committee discusses all drafts with each relevant technical agency (the initiators)

- The Pansus report is read before the fourth plenary session. Prior to closing, all factions sum up their Stemotivering (final perspectives). Finally, the Bupati addresses the session.

Both methods leave little or no room for public participation. Another weakness of the process followed in Tanjabbar lies is that the initiator's interests heavily influence the final regulation. Little attention is paid to the substance, or to whether the regulation is consistent with regulations for other sectors.

In general, no districts in Jambi, including Tanjabbar, have adopted a participatory policy-making mechanism in line with the objectives and spirit of decentralization as laid out in Law No. 22. The major local government decrees (Bupati/Mayor/Governor) issued in 1992 and 1993, refer to the old pattern of policy-making (Act No.5/1974 and its operational regulations). Therefore, new regulations on public participation are needed, allowing active public involvement at all stages, from policy initiation to 


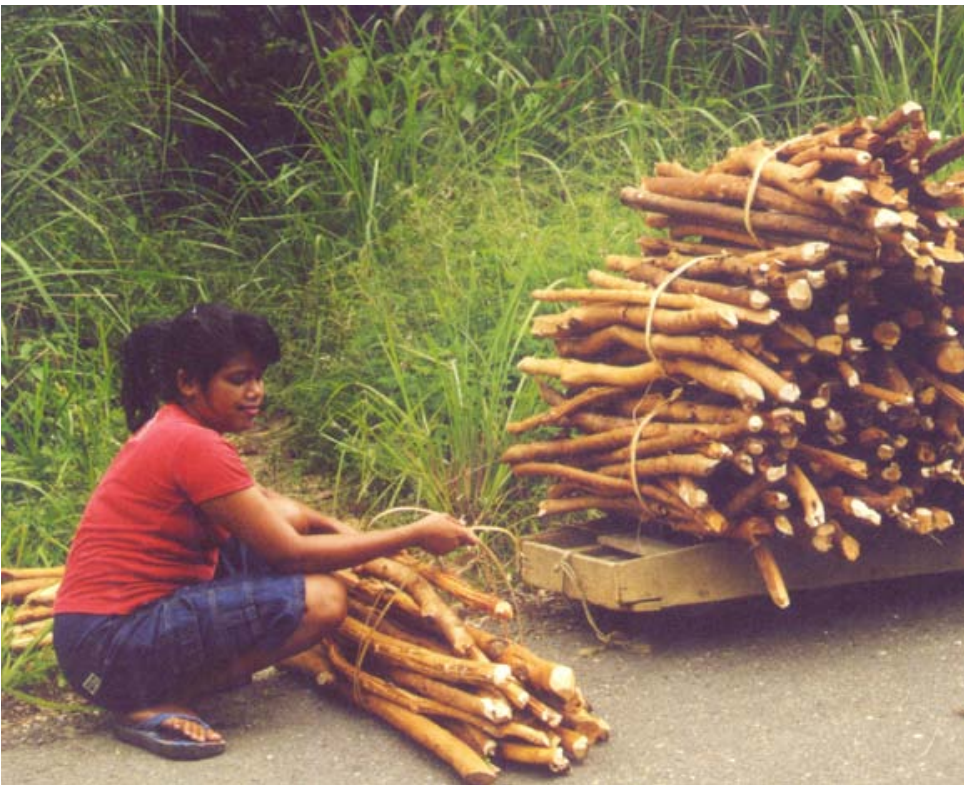

Photo by Toni Djogo

implementation

Ideally, a more comprehensive process might allow the public to consider issues such as how deforestation contributes to chronic flooding problems, a shortage of village firewood and future building materials, and less land for smallholder agriculture as forest areas are converted to other uses.

\section{Legal Principles}

An understanding of legal principles will determine the quality of legal drafting in the final policy. Our review of Tanjabbar's forestry policies ${ }^{12}$ highlighted the following basic principles:

1. District regulations should not contradict higher regulations. A local policy is contradictory if it regulates something that is not under district authority; if its technical or procedural aspects and contents are not consistent with higher regulations; or if it refers to now defunct higher regulations.

2. National regulations need to be reviewed and reformed to allow districts to issue policies based on legitimate local needs and aspirations, provided they do not contradict widely accepted national principles. Often districts implement divergent policies because higher regulations do not reflect district realities, or because districts see them as serving powerful interests in Jakarta. A process of legal drafting in Jakarta involving the affected districts would ensure that higher regulations were applicable, equitable and relevant to local stakeholders' needs. This would help ensure district compliance.

3. National and District regulations should be consistent with recognized indigenous laws and norms. In (centrally issued) Act No. 22/1999 Article 93 (1) regarding Recognition of the Diversity of Indonesia's Villages, the existence of local (village or customary) laws is understood and accepted. PP No. 76/2001 concerning
Generic Guidelines with Regard to Village Settings further emphasizes the operational regulations. This PP (a centrally issued regulation) reintroduced the acknowledgement of customary peoples and their autonomy, which was omitted from Act No. 5/1979 under the New Order regime.

4. Local regulations should not contradict basic principles of good governance, such as:

a. Formal rules, such as accuracy (clarity on the subject, content and meaning), fair play and avoiding procedural misuse;

b. Considering philosophical, judicial, sociological aspects, and formal legal certainty;

c. Including principles in the content concerning: formal legal certainty, trust, emerging expectations, equity, accuracy, balance, misuse of power and arbitrary prohibition.

5. Local regulations should not have negative ecological, environmental or economic impacts either locally or for neighbouring regions.

The above legal principles are highly recommended to avoid formulating and implementing defective policies and laws. A defective law, however, can be revoked by an authorized institution (under the process set out in the national legal framework for decentralization) or through the Supreme Court via the material test mechanism.

\section{Why is public participation needed?}

Public participation in policy-making is high on the decentralisation agenda, mandated by Act No. 22/1999, Act No. 41/1999 ${ }^{13}$, and Act No. 34/2000 to Act No. 18/1997. This means the law should guarantee public participation. Positive results include:

1. Local regulations strongly based on the people's interests and needs. The regulations will be more suited to the real world, and more likely to meet local expectations.

2. Encouraging local people to be more law-abiding and socially responsible. The public is more likely to comply with regulations that they actively participated in creating.

3. Empowering local governments to democratise the policy-making process, and become more accountable to their constituents. Open consultation with stakeholders, such as universities, NGOs and the general public, allows "checks and balances" to come into play.

In Jambi Province, public participation has been encouraged, for example in the Regional Development Program (Propeda). ${ }^{14}$ This is an encouraging step, opening the way for further participatory policymaking mechanisms to be developed.

\section{Conclusions and Recommendations}

Having reviewed Tanjabbar's local forestry policymaking processes, we conclude:

1. Policy-making mechanisms need to be reformed, due to:

a. Basic procedural weaknesses. 
b. Unclear contents and inapplicable policies, making implementation difficult on the ground.

2. Local regulations should be publicly, regionally and nationally oriented towards sustainable use of local forest resources.

3. Public participation is important to avoid laws that only benefit certain individuals or groups. A clear mechanism is necessary to local people voice their opinions and aspirations, and be actively involved in local policy-making and implementation.

We recommend:

1. The national government should work with district governments to establish a framework for developing district regulations capable of meeting local needs in line with commonly accepted national standards.

2. Tanjabbar district government should conduct a judicial review, overview and evaluation of local forestry regulations, involving a wide range of local stakeholders.

3. Public participation should be improved in the following ways:

(1) Develop a regulation that will standardize and legalize mechanisms for public participation. It can be used to guide local government in making local laws and regulations that comply with good governance principles. It will also strengthen public trust and compliance.

(2) Provide sufficient human and financial resources. It is also important the regional government supports the 'public participation fund' (Dana Partisipasi Masyarakat, DPM) from the regional budget (APBD), based on the planned local legislation programs.

(3) Public participation in decisions to issue $\mathrm{HTI}$ permits for plantation forestry. These permits have serious implications for the future of Tanjabbar's forests, but currently need only a letter from recommendation from the district head to the central Ministry of Forestry.

Public participation can be achieved through:

(a) Policy research and formal academic recommendations (naskah akademik);

(b) Open discussions such as seminars and workshops;

(c) Policy memos or policy briefs - developed with local stakeholders and widely distributed;

(d) Publishing local policies in printed and electronic media;

(d) Public hearings in local parliament; and

(e) Distributing draft regulations to various stakeholders, asking for and using feedback to formulate final regulations.

\section{Endnotes}

${ }^{1}$ Perda No. 21/2001 regarding Taxation of By-products from Forest Utilization (hereinafter Perda IPHHI); and Perda No. 15/2002 regarding Forest Products Taxation (RHH).

2 For example, a Bupati's decree No.189/2003

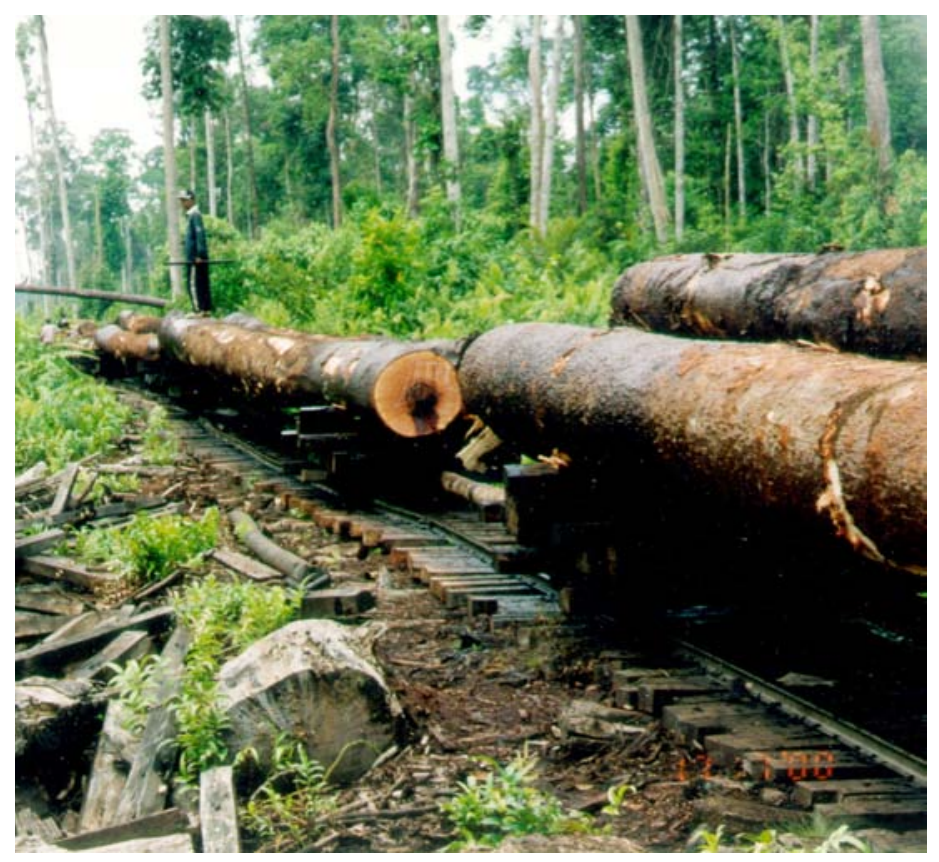

Photo by Chandra Budi

regarding the Implementation of Perda IPHH provided the legal basis for implementing district forestry regulations.

${ }^{3}$ During the 'padu serasi' process, forestry maps and provincial spatial plans were integrated, leading to the excision of significant areas from the state forest zone. This was formalized in the revised provincial spatial plan in 1999.

${ }^{4}$ Ministerial Decree No. 05.1/Kpts-II/2000 regarding Criteria and Standards of Licensing Forest Product Utilization and Collection in Natural Forests, (now replaced by Ministerial Decree No. 541/Kpts-II/2002).

${ }^{5}$ See footnote 3 . This regulation also contradicted PP No. 25/2000 regarding The Distribution of Authority Between Central and Provincial Government,

${ }^{6}$ PP No. $34 / 2002$.

${ }^{7}$ Perda No. 13/2002 Article 8:5.

${ }^{8}$ Keputusan Menteri Kehutanan No. 64/2001; Surat Menteri Kehutanan No. S.47/MENHUT-VI/2004 tanggal 18 Febrauari 2004 perihal Pengembangan Areal Hutan Tanaman PT Wirakaraya Sakti di Propinsi Jambi. As most of the WKS concessions overlap with the neighbouring districts, it is difficult to give an exact figure for WKS holdings within Tanjarbar district.

${ }^{9}$ According to sources within the district, the Ministry will soon release a HTI license over the PT Hatma Shanti area.

10 Law No. 22/1999 on decentralization and Law No.25/1999 on fiscal balancing and Law No. 41/1999 on forestry.

11 See also papers written by Fauzi Syam, PSHK-ODA entitled : 'Partisipasi publik terhadap kebijakan publik di propinsi Jambi' (2002,); 'Demokratisasi pembuatan peraturan daerah di propinsi Jambi: upaya 
mewujudkan hukum yang aspiratif dan berwibawa (2000); 'Increasing public participation in local policymaking (2000) and other relevant papers presented to seminars and workshops in Jambi province.

${ }^{12}$ That is IPHHI, IPHH and RHH. See also Kumpulan Modul PSHP UNJA (2000).

13 Forestry Law No. 41 issued in 1999 Article 68 entitled "Public Participation" explicitly states that the public has the right to receive good quality environmental services from forests. The public also has the right to information concerning forest land use, utilization of forest products, etc., with emphasis on the participatory mechanism in the local policymaking process. Another regulation stipulating these issues is Act No. 34/2000 issued in 2000, Article 4 (5) regarding Local Taxes and Retribution, which states that the public must be informed of pending new or altered local regulations concerning revenue from permits.

${ }^{14}$ See the Local Regulation regarding Propeda in Jambi Province chapter VII (Perda No. 14A/2001).

Sudirman of PSHK-ODA; Dede William and Siân McGrath of CIFOR prepared this Decentralisation Brief drawn from the report District Forest Policy-Making under Decentralisation: Processes, Implementation and Impacts - a case study of Tanjung Jabung Barat, Jambi. This work has been funded by ACIAR and DFID under the project: Can Decentralisation Work for Forests and the Poor? The opinions expressed herein are those of the authors and do not necessarily reflect the views of funding agency.
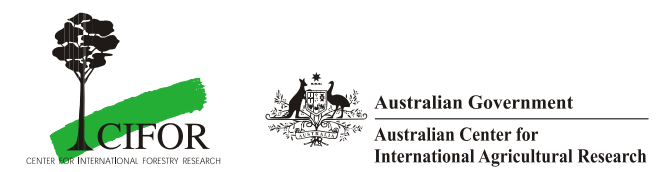
